\title{
Outreach Activities for Librarian Liaisons
}

\section{Isabel D. Silver}

Isabel D. Silver, director of Instruction and Academic Outreach, at the George A. Smathers Libraries, University of Florida, was previously Assistant Dean at the Graduate School of Library and Information Science, University of Illinois, and has a Ph.D. in Public Policy and Administration.

Correspondence concerning this column should be addressed to Barry Trott, RUSQ Editor, 7770 Croaker Rd., Williamsburg, VA, 23188; e-mail:btrott@wrl.org.
The role of the library liaison is evolving as user needs and library resources are changing. In this column, Isabel D. Silver, director of Instruction and Academic Outreach at the George A. Smathers Libraries at the University of Florida describes a new model for academic liaisons that can help to increase engagement with various library user communities.-Editor

$\mathbf{T}$

he academic librarian role has been identified by the following titles, depending on the intended emphasis of the role: bibliographer, selector, subject specialist, subject librarian, or liaison. ${ }^{1}$ All of these titles have been used at the University of Florida libraries at one time or another, and many of them have been used simultaneously. The academic "library liaison," "liaison librarian," or "librarian liaison" title is increasingly used by institutions to reflect a refocusing from collections to user services. ${ }^{2}$ This role has been evolving ever since the 2001 RUSA Committee report, which identified five core "liaison" activities, largely revolving around the traditional collection development responsibilities by subject specialists or departmental librarians in an academic atmosphere of clearly-defined disciplines. These core definitions are the following:

1. Liaison work is the process by which librarians involve the library's clientele in the assessment and satisfaction of collection needs.

2. Liaison work includes identifying user needs, evaluating existing collections, removing extraneous materials, and locating resources that will enhance the collections.

3. Liaison work enables the library to communicate its collection policies, services and needs to its clientele and to enhance the library's public relations.

4. Liaison work enables the library's clientele to communicate its library needs and preferences to the library staff and governing body.

5. Librarians with collection development responsibilities have various titles, including acquisitions librarians, bibliographers, collection development librarians, liaisons, selectors, and subject specialists. ${ }^{3}$

Changes to the liaison role have been sparked by the trend in academic disciplines toward interdisciplinary research and teaching. The library liaison role has also been influenced by various academic librarianship trends making it incumbent upon librarians to reach out to users to remain relevant in an increasingly digital age. Other trends in academic librarianship, including library budget cuts, reduced purchasing power, the availability of electronic resources, and the decreasing 
need to visit the library or consult a subject specialist, have increased the sense of urgency to foster new service roles based on an outreach-centered paradigm. ${ }^{4}$

The academic librarian liaison role aims to facilitate communication with library users, connect users to library resources and services, improve overall library services to campus users, and provide much more visibility to the library, given that it is no longer necessary to step over the physical library threshold. ${ }^{5}$ The liaison role has expanded to include greater marketing of library services and resources to academic departments, and their faculty and students. The role also includes the development of communication channels and the maturation of two-way communication with academic department clientele. Moreover, the role has expanded to include the development of a collaborative relationship with faculty leading to an eventual partnership in higher education and research. ${ }^{6}$ In summary, the current liaison role is evolving into a stronger partnership with faculty, and is increasingly expressed through greater involvement in teaching students and supporting faculty research.

Given the increasingly broad scope of responsibilities and corresponding activities of the librarian liaison, the role is currently undergoing substantial reconsideration and reconfiguration. A 2013 Association of Research Libraries report, "New Roles for New Times," discusses a new liaison outreach model that focuses on engagement. Engagement, in turn, requires a user-centered, outward focus. This focus involves building strong relationships with faculty and students. Engagement also means working with users by understanding their needs and practices, and establishing collaborative partnerships that serve to empower student learners and enhance scholarly productivity. It requires reaching out beyond the library to interact with surrounding communities. This engagement model is increasingly supported by library liaisons in practice and reflected in the literature. ${ }^{7}$

The outwardly-focused engagement role includes many of the following activities:

- advocacy and consultation services, such as promoting current and new and innovative library services to users

- providing information literacy instruction

- developing and maintaining collections, increasingly in partnership with faculty

- offering subject-specific customized research services

- providing course-integrated library instruction and participating in curriculum development

- referring researchers to functional specialists (e.g., copyright, open access, data management, digital humanities)

- representing user needs to library decision-makers

- increasing collaboration and partnerships with faculty ${ }^{8}$

To ascertain current and desired outreach activities at the University of Florida Libraries, and to provide outreach suggestions and possibilities for new and veteran liaison librarians alike, a small working group of librarians at the George A. Smathers Libraries, University of Florida, launched a brief
"Library Liaison Best Practices Survey" (March 2014) to determine the answers to the following questions:

- How are liaisons currently reaching out to faculty?

- From the liaison's perspective, what outreach activities to faculty have been most effective?

- How are liaisons currently reaching out to students?

- What liaison activities would librarians want to pursue given sufficient time and/or resources?

- What activities would liaisons engage given the time and/ or resources? ${ }^{9}$

The survey was sent to 107 librarians, and 28 responses (26 percent) were received. Responses basically fell under the following general categories:

- communication efforts and personal contact

- instruction programs

- special programs and events

- university/college/department participatio

- collaboration

This paper is designed to help both new and more experienced liaisons, and supervisors, as they seek to promote the library as an invaluable resource and offer timely and relevant services to campus users. Consequently, the data collected from both the library literature and the survey have been divided into three role phases: (1) for the benefit of beginning liaisons building core outreach services; (2) for liaisons with basic e experience and ready to progress to more unique and specialized services to meet the clientele needs; and (3) for veteran liaisons who would like to develop closer partnerships with faculty and possibly involving collaborative teaching and research.

\section{LIAISON OUTREACH PHASE I: INTRODUCTORY COMMUNICATIONS}

The early phase of outreach focuses on making introductions: introducing yourself and promoting library services and resources. It requires meeting users for relationship-building, creating trust, and establishing yourself as a "go-to" personprogressing gradually to more collaborative relationships. ${ }^{10}$ Numerous and various means of communication are available to enhance your presence; different media can be used for greater effectiveness, such as conventional email messages, face-to-face contact, and social media.

The importance of personal contact, communication, and visibility cannot be overstated. Not surprisingly, studies confirm that faculty who receive more services or communication from their liaison are more satisfied with their liaisons than those who receive less contact. Similarly, liaisons spending more time in active contact activities experienced more satisfaction with both their departments and their own liaison performance. ${ }^{11}$ 


\section{FOR YOUR ENRICHMENT}

The following suggested activities, all recognized as effective and recommended by UF librarians, this survey, and the liaison literature, increase your presence, visibility, and networking opportunities on campus.

\section{COMMUNICATION: INTRODUCING YOURSELF AND PERSONAL CONTACT}

It is not possible to overemphasize face-to-face contact, hallway conversations, roaming, and office visits.

- Become familiar with departmental webpages and newsletters.

- Introduce yourself in person, to: department chair, department faculty as a whole, and individual faculty.

- Send an introductory message to the department chair and faculty about library resources, services, news, and events, and also your services.

- Request permission and place an initial news column in the department mass email.

- Request an introduction and brief statement at the beginning-of-the-academic year college/department meeting.

- Cold-call targeted individuals (e.g., department chair, college dean-perhaps request introduction from Library Dean or your library department chair). ${ }^{12}$

- Be friendly and start "hallway conversations": have ready a 3-minute elevator speech (who you are what you do, resources and services the library provides, special services you can provide)

- Seek permission and access to post regular updates through the faculty email.

- Identify and introduce yourself to targeted student organizations.

- Request invitations to student-only meetings.

- Provide a brief presentation when possible.

- Network: to whom can your initial contacts introduce you (e.g., online instructors, researchers, faculty teaching high enrollment classes)?

- Identify influential departmental contacts, departmental programs and student services, culture and communication styles, depending on the department (e.g., college dean, department chair, administrative assistant, friendly faculty, key researchers, and IT staff) to contact and network.

- Make appointments with targeted individuals.

- Office visits: consider visiting in twos, bringing along another librarian (for additional support, specialist input, and/or peer suggestions).

- Respond to individual requests for assistance (e.g., reference, research, materials, scholarly communications).

- Provide personal orientations and tours to targeted individuals and small groups.

- Use the reference desk encounter to promote future contacts.

\section{INSTRUCTION}

- Make class visits/presentations on library resources and research.

- Invite faculty to stay, for several reasons: it is important that they are aware of the content covered, they are likely to appreciate your knowledge skills and abilities, and they might learn something that they wouldn't otherwise!

- Promote one-on-one reference and research assistance.

- Offer to provide class-specific orientations and tours in the library.

\section{CREATING A UNIVERSITY/COLLEGE/ DEPARTMENT PRESENCE: BE AVAILABLE}

The importance of visibility, being readily available, establishing a presence, and offering assistance cannot be overstated.

- Timing is key; be sensitive to semester highs and lows. ${ }^{13}$

- Use the college and departmental mass email, and other lists, to inform about library services (e.g., workshops, trainings, databases, course reserves/e-reserves, etc.) for both students and faculty, and also library policies and procedures.

- Expand your clock to work earlier or later depending on key college, department, or other academic unit activities (e.g., research showcase, student exhibits, and receptions).

- Consult with faculty and students about collection management issues, library choices, and announcements.

- Attend student capstone presentations, thesis and doctoral defenses, productions, and/or performances.

- Join disciplinary electronic discussion lists.

- Learn about the uniqueness of each academic unit: its culture, academic cycles, major assignments, and communication styles and specific stresses.

\section{LIAISON OUTREACH PHASE II:TAKE ACTION}

Liaisons typically continue to perform many of the core activities of the early phase while becoming increasingly involved with more in-depth communication and information-sharing with faculty and students. This next phase emphasizes marketing library resources and services and actively participating in collection development with departments through the establishment of two-way communication regarding these activities and clientele needs. It also encompasses the concept of "embedded" liaison work: not working solely within the library but increasingly becoming a part of the department, its courses, activities, and research. ${ }^{14}$ The focus here is to engage in two-way communication, seeking informal feedback to improve library resources and services, and greater presence and participation in the liaison department. While following lists aim to 
be inclusive, you will choose those activities that are most feasible and effective.

\section{COMMUNICATION AND PERSONAL CONTACT: BUILD RELATIONSHIPS, CULTIVATE ADVOCATES AND CHAMPIONS}

- Provide regular and periodic communication about new and ongoing services (e.g., open access, copyright, data management workshops, events).

- Try different communication vehicles; "there is no one best method"15: email groups, department newsletter, websites, brochure delivery, fliers, posters, and social media. Note: while email is a preferred tool by liaisons, owing to its ease and efficiency, the telephone could be used to much greater extent, especially because a recent study indicated that this was preferred by faculty. ${ }^{16}$

- Meet and communicate regularly with faculty and students.

- Send out a welcome message every semester (ask colleagues for an effective sample).

- Create and send out your own periodic library newsletter.

- Ask administrative personnel to post mundane information (e.g., library hours, workshops) on their monitors, bulletin boards, and websites.

- Intensify contacts with users; for example, invite key people, such as student leaders, graduate coordinators, and faculty to coffee breaks or lunch (everyone needs to eat lunch!).

- Provide individual consultations, reference, and research assistance to faculty and students (don't forget about the functional specialists!).

- Become familiar with individual faculty research interests; send personalized emails based on research interests.

- Know what is happening with individual faculty and write congratulatory notes for research, publications, awards, grants, etc.

- Extend personal invitations to library events in addition to the general invitations and updates

- Explore the possibility of holding office hours off-site and in the academic unit as a more significant way to become embedded in a department.

- Advocate for the library so that its resources, services, and needs are represented to your liaison units. ${ }^{17}$

- Welcome new faculty and offer to provide a library orientation; consider following up the orientation "with a meeting over coffee to further the personal relationship."18

- When people are pleased with your assistance, ask them to share this service with their colleagues and students to increase outreach.

Consider liaison teamwork in outreach and engagement, especially including another librarian liaison in an overlapping subject area or a functional specialist (e.g., scholarly communications, publishing/open access, digital humanities, data management. ${ }^{19}$

\section{INSTRUCTION}

- Provide topical workshops (e.g., RefWorks, EndNotes, plagiarism).

- Make presentations to department faculty, graduate students, teaching assistants, and research assistants, as applicable.

- Offer individual or small group instruction to faculty and students. Also, consider ways to make it easy for users to make appointments, e.g., LibCal on your website or access from the department website.

- Increase library instruction to departments and classes:

- Provide office hours to students.

- Search all course syllabi in order to evaluate and identify the need for specific guides to library resources within units, and to respond to course and discipline needs. ${ }^{20}$

- Create disciplinary, course-specific, and/or assignment LibGuides as needed.

- Become embedded in courses by partnering with instructors. ${ }^{21}$ Obtain access to and presence within the course management system (CMS) to

○ provide library links, tutorial links, and other information;

- insert subject, course, and assignment-specific LibGuides;

- answer reference questions and provide research assistance;

$\circ$ participate in discussion boards as necessary (with faculty permission); and

- provide consultation to both instructor and students as needed.

- Provide information literacy instruction during class.

- Offer one-on-one consultations with students.

- Sit in on classes for greater familiarity with demands of the course and outreach to students.

- Support new learning techniques and technologies in the unit's curriculum.

- Enable and/or create student internships as appropriate.

- Coordinate with other liaisons about guides of general interest to all users, and also about the provision of library educational sessions. ${ }^{22}$

\section{SPECIAL PROGRAMS/EVENTS}

In additional to customized instruction to faculty and students, special programming for departments can be an especially effective way to provide assistance to campus users and promote the library. ${ }^{23}$ 


\section{FOR YOUR ENRICHMENT}

- Schedule special library programs with your faculty/departments to be held at the library (e.g., student research showcase, film showings/series, faculty speaker event/ series (e.g., Authors@UF), International Education Week, meet and greets, weekend workshops).

- Hold contests to attract students to the library and then highlight events or collections.

- Sponsor a library award to be given to members of UF or the community.

- Create topical library exhibits.

- Support college/department special events (e.g., assistance, participation, exhibits).

\section{UNIVERSITY/COLLEGE/DEPARTMENT ACTIVITIES}

- Become aware of college/department activities (e.g., journal clubs, research priorities and needs, departmental policies, seminars, table/exhibit for research days, and special events, etc.) and participate for increased participation and customized services.

- Seek invitation/join college and departmental committees and contribute.

- Faculty hiring process (in support of the academic unit): - Offer to meet with prospective faculty during the campus visit to give a tour of the library and collections of special interest.

- Offer to serve as an outside member of search committees.

○ Attend any open candidate presentations and greeting opportunities.

- Provide feedback to faculty on curriculum requirements and library resources and services.

- Advocate for your academic units so that their interests are represented to the libraries. ${ }^{24}$

- Become more integrated into life of students.

- Request referral of students needing extra assistance.

- Participate in departmental new-student orientations.

- Submit business cards for insertion into new graduatestudent packets.

\section{COLLECTION DEVELOPMENT}

- Develop and maintain comprehensive knowledge of the information resources pertinent to your liaison areas.

- Support collection requests.

- Evaluate subject coverage and select appropriate materials to ensure that the unit's subject areas are current and adequately represented in the collection to meet the information needs of faculty, staff, and students.

- Provide trial subscriptions and seek feedback.

- Evaluate user satisfaction with the acquisition process.

- Select appropriate electronic resources to support the academic unit.
- Notify individual faculty about new materials of interest to their research or teaching.

- Create a collection website as an instrument to notify faculty of resources and issues.

- Seek feedback:

- Meet with department chair regarding collection management issues and decisions.

- Solicit and encourage ongoing faculty, staff, and student input regarding new items (regardless of format) for the collection.

- Conduct in-depth meetings focusing on two-way communication about collection development issues, choices, and decisions (discuss funding, what you can do to help, and how they can help).

- Represent the unit's interest in implementing the collection development policy of the libraries..$^{25}$

\section{DEVELOP SUBJECT EXPERTISE}

To facilitate a partnership between librarian liaisons and colleges, and in preparation of a more advanced level of collaboration with faculty, the development of subject expertise is essential. ${ }^{26}$

- Develop and exhibit a passion for the subject and learn the language of the subject field.

- Enroll in college courses to increase knowledge of subject.

- Develop knowledge of the disciplinary/professional associations (local, state, and national) and their activities, conferences, and committees.

- Join electronic discussion lists.

- Join association committees.

- Attend conferences.

- Deliver a poster or paper at the conferences.

- Attend college events (symposia, research showcases, dissertation defenses, and receptions).

A note of encouragement: be persistent! Academic departments and disciplines vary in their needs, academic culture, and communication styles. Some departments will be more difficult than others to integrate. Some faculty are already familiar with, and have immediate access to, the essential electronic resources in their field. Very frequently, a major obstacle to library instruction is a lack of classroom time (consider working with faculty to create an "outside-of-theclassroom information literacy activity). ${ }^{27}$ Librarian liaisons need to adjust outreach methods depending on the clientele. Patience, perseverance, and the willingness to try are necessary attributes of a successful librarian liaison. Continue to build on earlier steps and success, and use these college/departmental activities as opportunities to promote the library, resources, services, and yourself. ${ }^{28}$ 


\section{LIAISON OUTREACH ADVANCED PHASE: ACADEMIC COLLABORATION AND PROGRAM EVALUATION}

More experienced subject-specialist librarian liaisons are in a good position to engage with academic faculty in a collaborative manner: co-teaching, teaching a departmental credit course, and forming research partnerships. Some of the following activities are opportunities for collaboration that must be earned through contributions and relationships (e.g., serving on the curriculum committee, joining the college accreditation team, and conducting research with faculty). They are posed as aspirational goals for most library liaisons, but certainly are attainable and some of these activities have been achieved by librarian liaisons at the University of Florida. At this stage, it is also important to conduct library and liaison activity assessments, admittedly a weak link in most libraries. ${ }^{29}$ Assessments are needed to determine faculty and student awareness of, and satisfaction with, and liaison services, especially in comparison to the liaison's impressions and choices.

\section{INSTRUCTION}

- Consult with faculty about the design of assignments to to encourage and maximize the use of library resources.

- Provide stand-alone customized instruction for individuals or small groups of users, possibly engaging functional specialists (e.g., database, data management, or data curation classes, and scholarly communications, copyright, open access classes).

- Create educational learning objects to aid faculty, staff, and students in acquiring information literacy and critical thinking skills.

- Provide support for departmental distance education programs.

- Provide information literacy course-integrated instruction.

- Co-teach with departmental faculty.

- Teach a departmental credit course.

- Create a new online course.

- Produce professional quality videos for instruction and library orientation.

- Develop an outreach instruction program to research and teaching assistants to indirectly improve library services to students.

- Consider establishing an appropriate mentoring program for students in collaboration with the department.

\section{SPECIAL PROGRAMS/EVENTS}

- Continue to initiate and collaborate with departments on planning and implementing co-sponsored special events.

\section{COLLABORATIVE RESEARCH}

- Establish research partnership with academic faculty or join faculty research team to co-publish.

- Collaborate on external or internal (university or library) grant opportunities.

- Host workshops in the library's digital scholarship lab (DSL) or encourage the library to establish a DSL for liaisons to host workshops or provide individual consultations with faculty and students.

\section{UNIVERSITY/COLLEGE/DEPARTMENT ACTIVITIES}

- Participate on departmental curriculum committee.

- Support departmental accreditation efforts (see your institution's accreditation website), and work with faculty to meet official departmental learning outcomes.

\section{ADVANCED SUBJECT EXPERTISE}

- Review dissertations submitted by graduate students and attend dissertation defenses.

- Address the departmental needs and work with faculty to meet learning outcomes (see above).

- Join college accreditation team.

- Assist/join faculty research teams.

- Conduct research with faculty.

\section{LIAISON OUTREACH PROGRAM EVALUATION}

- Needs assessment:

- Solicit informal feedback from your units regarding their needs, your activities, and suggestions for improvement.

- Collect more formal qualitative feedback from faculty and students on their user needs and research practices (consider surveys, focus groups, evaluation forms, etc.).

- Provide an annual report of your activities, successes, program strengths, and barriers and goals for improvement to your supervisor. ${ }^{30}$

- Consider writing a report for your academic units and request feedback.

\section{FINDINGS}

When asked what activities they would undertake if time and resources were available, UF respondents indicated that spending more time with users-engagement-was a top priority. The responses support the turn toward greater engagement as an effective academic library strategy. UF respondents were especially interested in creating new events with 


\section{FOR YOUR ENRICHMENT}

departments, meeting faculty and conducting more office visits, offering greater faculty research assistance, and hosting interactive events with students, such as contests. Librarians also indicated a desire to upgrade library marketing and instruction through the creation of new video orientations, workshops, information literacy courses, and more coursespecific LibGuides.

\section{CONCLUSION}

This document is meant as a guide to aid individual library liaisons in determining the most effective activities for their own unique situation. Given the realistic limitations of staff time and resources available to staff, each librarian liaison needs to determine the most cost-effective outreach strategies to achieve both efficiency and effectiveness-for the library, for their clientele, and for their own professional satisfaction. The emphasis is on contact, two-way communication, responsiveness, and engagement. With progressive success, liaisons can look forward to a deeper level of interaction, collaboration, and collegiality with faculty, and personal job satisfaction. The library, the librarian liaison, the liaison departments, and the university all stand to gain from an active, well-supported librarian liaison program.

\section{References}

1. Julie Arendt and Megan Lotts, "What Liaisons Say about Themselves and What Faculty Say about Their Liaisons, a U.S. Survey," portal: Libraries and the Academy 12no. 2 (2012): 155-77.

2. Louise Cooke et al., "Evaluating the Impact of Academic Liaison Librarians on Their User Community: A Review and Case Study," New Review of Academic Librarianship 17, no. 1 (March 2011): 5-30, http://dx.doi.org/10.1080/13614533.2011.53909.

3. James Thull and Mary Anne Hansen, "Academic Library Liaison Programs in US Libraries: Methods and Benefits," New Library World 110, no. 11/12 (2009): 529-40, http://dx.doi .org/10.1108/03074800911007541.

4. Scott Walter and Paula Kaufman, "Service is Sovereign: Strategic Change and the Future of Library Service" (address presented at the LibraryConnect Seminar 2008, Tokyo, Japan; Singapore; Selangor Darul Ehsan, Malaysia; and Bangkok, Thailand: JulyAugust 2008).

5. Thull and Hansen, "Academic Library Liaison Programs in US Libraries," 529-40.

6. Cooke et al., "Evaluating the Impact of Academic Liaison Librarians on Their User Community," 5-30; Jo Henry, "Academic Library Liaison Programs: Four Case Studies," Library Review 61, no. 7 (2012): 485-96; http://dx.doi.org/ 10.1108/00242531211288236.

7. Arendt and Lotts, "What Liaisons Say about Themselves," 155-57; Cooke et al., "Evaluating the Impact of Academic Liaison Librarians on Their User Community," 6; Henry, "Academic Library Liaison Programs"; Janice M. Jaguszewski and Karen Williams, New Roles for New Times: Transforming Liaison Roles in Research Libraries 4, no. 13 (Washington, DC: Association of Research Libraries, August 2013), 1-17; Nancy Kranich, Megan Lotts, and Gene Springs, "The Promise of Academic Libraries: Turning Outward to Transform Campus Communities," College E Research Libraries News 75, no. 4 (April 2004): 182-86; Tina Schneider, "Outreach: Why, How and Who? Academic Libraries and Their Involvement in the Community," in Outreach Services in Academic and Special Libraries, ed. Paul Kelsey and Sigrid Kelsey (Binghamton, NY: Haworth, 2003), 200; Thull and Hansen, "Academic Library Liaison Programs in US Libraries," 529-540; and Walter and Kaufman, "Service is Sovereign," 7.

8. Michele R. Tennant et al., "Customizing for Clients: Developing a Library Liaison Program from Need to Plan," Bulletin of the Medical Library Association 89, no. 1 (January 2001): 11, 8-20; Onda Bennett and Karen Gilbert, "Extending Liaison Collaboration: Partnering with Faculty in Support of a Student Learning Community," Reference Services Review 37, no. 2 (2009): 131-42. See also John Rodwell and Linden Fairbairn, "Dangerous Liaisons? Defining the Faculty Liaison Librarian Service Model, Its Effectiveness and Sustainability," Library Management, 29, no. 1 (2008): 116-24; E. M. Wilson, "The Role of Library Liaison as Consultant," Kentucky Libraries 77, no. 1 (2013): 14-19.

9. Sara Gonzalez, Physical Sciences Librarian; Rae Jesano, Health Sciences Librarian; Peter McKay, Business Librarian; and Isabel Silver, Director of Instruction and Outreach.

10. Arendt and Lotts, "What Liaisons Say about Themselves," 156; Sally Gore, "Cashing In: Social Capital and the Informationist," A Librarian by Any Other Name (blog), March 3, 2014, http:// librarianhats.net/2014/03/03/cashing-in-social-capital-and-the -informationist.

11. Arendt and Lotts, "What Liaisons Say about Themselves," 173.

12. Linda C. Butson et al., "You Have Become a Liaison Librarian, Now What? Getting In and Going Forward," poster, Health Science Center Libraries, University of Florida, Gainesville, Florida.

13. Ibid.

14. Arendt and Lotts, "What Liaisons Say about Themselves," 156.

15. Henry, 485-96.

16. Ibid.

17. Tennant, Butson, Rezeau et al., 19

18. Henry, 485-496.

19. Butson et al., "You Have Become a Liaison Librarian, Now What?" 20. Ibid.

21. The draft ACRL Framework for Information Literacy for Higher Education (February 2014) emphasizes the partnership between librarians and faculty to integrate information literacy into course design and across the academic curricula. See also: Corey M. Johnson and Sarah K. McCord, and Scott Walter, "Instructional Outreach Across the Curriculum: Enhancing the Liaison Role at a Research University," Reference Librarian, 39: 82 (2003): 19-37.

22. Tennant, Butson, Rezeau et al., 20.

23. Kranich, Lotts, and Springs; and "UF Library Liaison Best Practices Survey" (March 2014)

24. Tennant et al., "Customizing for Clients," 19.

25. Ibid., 19-20.

26. Ibid., 11 .

27. Thull and Hansen, "Academic Library Liaison Programs in US Libraries," 529-40.

28. Butson et al., "You Have Become a Liaison Librarian, Now What?"; Thull and Hansen, "Academic Library Liaison Programs in US Libraries," 535-38.

29. Henry, 485-96.

30. Butson et al., "You Have Become a Liaison Librarian, Now What?" 